\title{
Sanal Gerçeklik Oyunlarındaki Mekân Algısı: PUBG Oyunu Örneği
}

\author{
Seher Özkazança, b, Tuğçe Esentürkc
}

\begin{abstract}
Özet
Yaklaşık 40 yıllık bir geçmişe sahip olan dijital oyun sektörü son on yıldır ivme kazanmış ve özellikle gelişmiş ülke ekonomilerinde yüksek kazanç sağlamıştır. Ekonomik krizlerden en az etkilenen sektörlerden biri olması ise sektörün cazibesini artırarak etki alanını büyütmüş ve yeni oyun ütopyaları üretilmeye başlamıştır. Her oyun ütopyasının bir oyun tahtası bulunmaktadır ki dijital oyun sektöründe bu; fiziksel mekân ve siber mekânın eklemlenmesi ile oluşan 'başkalaşmış' sanal mekânlardır. Sanal mekânlar tıpkı gerçek mekânlarda olduğu gibi yer işaretleri ve duyumla imgelenmektedir. Bu nedenle günümüzde ayna dünyalar olarak da adlandırılmaktadır. Bu konjonktürde mekânsal teorilerin ayna dünyalarda (sanal bir mekânda) algıyı nasıl etkilediğinin sorgulanması ve sanal gerçeklik oyunlarındaki kentsel organizasyonun mekânsal algı yaratıp yaratmadığının araştırılması çalışmanın temel amacını oluşturmaktadır. Çalışma kapsamında oldukça yaygın kullanılan PlayerUnknown's Battlegrounds (PUBG) oyunu seçilmiştir. PUBG sanal mekânlarındaki algilanabilirlik Lefebvre, Lynch ve Norberg-Schulz'un tartışmaları üzerinden kuramsal olarak değerlendirilmektedir.
\end{abstract}

Anahtar Kelimeler

\begin{tabular}{r} 
Anahtar Kelimeler \\
Sanal mekânlar \\
Mekânsal algı \\
Fiziksel çevre \\
PUBG oyunu \\
Makale Hakkında \\
\hline Geliş Tarihi: 02.01.2020 \\
Kabul Tarihi: 24.04 .2020
\end{tabular}

Doi: 10.18026/cbayarsos.669350

\section{The Perception of Space in Virtual Reality Games: PUBG Game Example}

\begin{abstract}
Digital games sector, which has a history of about 4 decades, has gained momentum in the last decade achieved high revenues in especially the economies of developed countries. The fact that it is one of the sectors that are affected by economic crises the least increased the attractiveness of the sector and grew its area of impact, and new game utopias started to be produced. Every game utopia has a board, in the sector of digital games; these boards are 'metamorphic' virtual spaces that are formed by augmentation of the physical space and the cyberspace. Just like in real spaces, virtual spaces are envisaged by bookmarks and sensation. This is why they are also known as mirror worlds today. Hence, the main purpose of this study is to question how spatial theories affect the perception in mirror worlds (a virtual space) in this conjuncture and investigate whether or not the urban organization in virtual reality games creates spatial perceptions. In the scope of the study, the very widely played video game PlayerUnknown's Battlegrounds (PUBG) was selected. PUBG, perceptibility in virtual spaces is theoretically discussed based on the discourses of Lefebvre, Lynch and Norberg-Schulz.
\end{abstract}

Keywords

Virtual spaces

Spatially perception

Physical environment

PUBG game

\section{About Article}

Received: 02.01.2020

Accepted: 24.04.2020

Doi: 10.18026/cbayarsos.669350

a İletişim Yazarı: sozkazanc@erbakan.edu.tr

b Dr. Öğr. Üyesi, Necmettin Erbakan Üniversitesi Şehir ve Bölge Planlama Bölümü, Meram/Konya, ORCID 0000-0001-7618-2494

c Şehir Plancısı, Necmettin Erbakan Üniversitesi Şehir ve Bölge Planlama Bölümü, Meram/Konya, ORCID 0000-0003-1073-4588 


\section{Giriş}

Teknolojinin gelişimi ile birlikte insanların gerçek mekânlar ile olan ikili ilişkileri, sanal ortamlara taşınmaya başlamıştır. Bu ilişkilerin günümüzdeki en net örneklerinden biri de başkalaşmış oyun tahtalarıyla sanal gerçeklik oyunlarıdır. Gerçek mekânlar, beden ile mekânın kavranması ve deneyimlenmesi sonucu algılanabilmektedir. Bu doğrultuda bedenler mekânlarla ilişki kurulmasını sağlayan bir araç konumundadır. Deneyimlemeler sonucunda insan davranışları, mekânın fiziksel ve sosyal özellikleri ile şekillenmektedir. Anlam kazanan bu deneyimler hareket kavramı ile birlikte değişir ve gelişir.

Bilgisayar ekranlarının paralel evrene açılan kapılar olarak tanımlanması, teknolojinin mekân ve zaman arasındaki dönüştürücü etkisine dikkat çekmektedir. Sanallığın içerisindeki bu başkalaşmış mekânlar, temel olarak bedensiz mekânlardır. Bedenin kavrayamadığı sanallıktaki algılanabilirlik düzeyi çalışmanın temel konusunu oluşturmaktadır. Gerçek mekânlardaki fiziksel çevrelerin bedenle kavranması sonucunda zihinsel kodlamalar başlamakta ve mekân imajı şekillenmektedir. Sanal mekânlardaki fiziksel çevre faktörlerinin gerçek mekânlar ile benzerlik göstermesi, bu ortamların bedensiz olarak nasıl algılandığı sorusuna dikkat çekmektedir.

Arttırılmış gerçeklik oyunlarında gerçek dünyadan ziyade planlanmış kurgu bütünlügü olan mekânlar yer almaktadır. Nitekim mekân tasarımcıları tarafından oyuncuların eylemleri yönlendirilmektedir. Sıradan bir park yeri savaş alanı haline gelebilir; nehir yatakları siper olabilir ve otobüs durakları veya yabancı gemiler bireydeki mekân algısını değiştirebilmektedir. Değişen bu algı bireyde merak duygusu uyandırmaktadır. Duyulan bu merak, sanallığın içerisindeki fiziksel çevrenin keşfidir, dolayısıyla, sanal mekân algısındaki en önemli faktör fiziksel çevre olarak karşımıza çıkmaktadır.

Oyuncu sanal mekânı yorumlarken, gerçek mekânı algılama sürecine benzer bir süreç yaşamaktadır. Kişi sanal deneyimde de fiziki dünyanın içerisindedir fakat duyu organları, bilişsel ve motor yetenekleri sanal gerçeklik sistemi tarafından gelen verileri yorumlamaktadır. Bu bağlamda, sanallıktaki fiziksel çevre mekânlarının yeniden yorumlanması, gerçek mekanların alg1 parametrelerini incelemeyi gerekli kılmaktadır. Bu kapsamda Lefebvre (1974); algilanan, yaşanan ve tasarlanan mekân olarak sinıflandırılan mekânın sırasıyla duyusal algı, tecrübe ve koda dayalı olduğunu savunmaktadır. Bu kodlanmış mekanların algılanan ve yaşanan mekanlarla olan ilişkisini ise Foucault (2005) heterotopya kavramı ile tanımlayarak temeldeki başkalaşmış (heteroptik) mekanların gerçek mekanlardaki gibi algılanan veya yaşanılan alan olarak kabul edilip edilemeyeceğini sorgulamaktadır. Böylelikle Foucault'nun tanımından hareketle heteroptik mekân olarak tanımlanabilen sanal mekanlardaki koda dayalı algı yönetimi ve gerçek mekân algısındaki bileşenler arasındaki benzerlikler ve farklılıklar dikkat çekmektedir. Kevin Lynch (1960) mekânın asıl anlamının bireylerin zihninde taşıdığı ortak imgeler olduğunu savunarak bu imgeleri "izler, sınırlar, bölgeler, odaklar ve işaret ögeleri" olarak tanımlamaktadır. Benzer bir şekilde "varoluşsal mekan" tanımı yapan Norberg-Schulz (1971) ise mekansal algıyı oluşturan elemanları "merkez veya yer (yaklaşma), yönler ve yollar (süreklilik) ile alanlar veya ilgi alanları (sınır)" olarak belirlemiştir; böylece mekânın fiziksel ögelerinin algı yönetimi üzerindeki kurucu ve değiştirici etkisine dikkat çekmektedir.

$\mathrm{Bu}$ bağlamda "heteroptik mekân" olarak tanımlanabilen sanal mekanlardaki algı yönetiminin analiz edilebilmesi için gerçek mekân parametreleri ile eşgüdümlü bir şekilde 
değerlendirilmesi gerekmektedir. Bu nedenle çalışma kapsamında; bir sanal gerçeklik oyunu olan PUBG içerisinde yer alan Erangel haritasındaki fiziksel çevre; Lynch ve NorbergSchulz'un mekansal alg1 parametreleri, Foucault'nun "heterotopya mekânları" tanımı ile birlikte Henri Lefebvre'nin mekansal üçlü (algılanan, tasarlanan, yaşanan) kuramındaki "eşzamanlılık, merkezileşme ve ilişkiler" olarak tanımladığı mekânsal analiz teorileri üzerinden kuramsal olarak değerlendirilmektedir. Çalışmanın temel amacı, oyun içerisindeki sanal çevrenin mekânsal algı yaratıp yaratmadığının incelenerek mekânsal algı teorilerinin heterotopik mekânlardaki kentsel organizasyonları değerlendirmede yeterli olup olmadığının sorgulanmasıdır.

\section{Gerçek Mekânda İnsan Davranışları Etkileşimi ve Mekânsal Algı Süreci}

İnsanlar kendi ihtiyaçları doğrultusunda çevreyi düzenleyerek yeni mekânlar oluşturmaktadır. Mekân, devingen bir olgudur. Bu devingenlikte insan, kendi değer ölçütleri ve ihtiyaçları doğrultusunda mekânı şekillendirirken, mekândan etkilenebilmekte ve yeni gereksinimlere yönelebilmektedir. Bu durum mekân ve insan etkileşiminin temel prensiplerini belirlemektedir. İnsan mekân üretiminde yer alırken aynı zamanda mekânın bileşenlerindeki en önemli etmendir. Bu anlamda, uzamsal boyutta insanın mekânla karşılaştı̆̆ında kurduğu başat ilişki tercihi amaca yönelik kullanımdır. Mekân ile ilişkiler kuran insan, içinde bulunduğu mekâna, zaman içerisinde zihinsel olarak farklı anlamlar yüklemeye başlamaktadır. Yüklenen bu anlamlar, mekân ve insan arasında bağımlı bir ilişkiye dönüşmektedir. Bu sayede insan-mekân ilişkisinde insanın mekândan etkilendiği kadar, mekân da insan sayesinde gelişmekte ve değer kazanmaktadır (Akgül, 2009).

İnsan zihnindeki mekân kavramı; genellikle fiziksel gerçeklikten çok düşünsel, kavramsal ve bilişsel boyutları ile temsil edilmektedir. Bu nedenle mekân kavramı, basit ve somut fiziksel boyutlara hem bağımlı hem de bunların ötesinde karmaşık olarak soyut ve kavramsal boyutlara sahip, insanın yaşamsal gerçekliği ile bütünleşik bir varlıksal boyutu olan yerle ilişkili bir olgu olarak tanımlanmaktadır (Torun, 2004).

Mekân; somut olarak algılanabilen ve soyut olarak imgelenen, algıyla anlam kazanan bir yapıdır. İnsan-mekân arasındaki ilişkiler deneyimleme ile gerçekleşmektedir. Deneyimleme sonucunda insan davranışları, mekânın fiziksel ve sosyal özellikleriyle şekillenmektedir. Fiziksel mekânların insan zihninde biçimlenme, deneyimlerle soyutlaşarak kavramsal kodlar oluşturulması ve bu kodların bireydeki mekân olgusuna anlam kazanması şeklindedir. Anlam kazanan bu deneyim, hareket kavramına bağlı olarak değişerek gelişmektedir. Kişi, mekânı kendince hatırlayabilmek için bir takım ek mekânsal bileşenlere ihtiyaç duymaktadır. Kişinin mekânı hatırlayabilmesi için ihtiyaç duyduğu bileşenlerin ürünü ise mekânın tanınması ve algılanmasıdır (Özen, 2006).

İnsanlar yaşadığı çevreden yararlanabilmek ve o mekâna uyum sağlayabilmek için mekânı tanımak zorundadır (Torun, 2004). Tanıma zorunluluğu içerisindeki insan, duyu organlarıyla çevresini duyumsamaya başlamaktadır. Fakat duyu organları her ne kadar bilgi depolama kapasitesine sahip olsa da mekân ve insan zihni için algılama ve depolama pratikleri her an değişebilmektedir (Akgül, 2009).

Algılama temel olarak bir deneyimleme sürecidir. Yani algılama mekânı duyum yolu ile yalın bir biçimde bilincine almak, duyumları yorumlamak, onları anlamlı hale getirmektir. Bu şekilde algı iki süreçten oluşmaktadır. İlki, mekândan gelen bilgileri duyularımız aracılığı ile yorumladığımız duyumsal süreç, ikincisi ise farkında olarak ya da olmayarak edinilen 
mekânsal bilgileri, yaşanmışlığa bağlı olarak zihnimizde yorumladığımız zihinsel süreçtir. İki sürecin devamlılığı ile deneyimlenen mekânlar anlam kazanarak algılanmaktadır. Fiziksel mekânların kavranıp, hissedilmesi ve yorumlanması insan zihninde bir araya gelerek mekânsal alg1 sürecini tamamlamaktadır (Akgül, 2009).

\section{Yeni Mekânların Keşfi, Sanal Gerçeklik Oyunları}

Teknolojinin gelişimi ile birlikte günlük rutinimiz gibi, yaşantımızın içerisinde geçirdiğimiz mekân kavramı da değişim geçirmektedir. Bilginin dijital veriye dönüşmesi ve iletimi ile başlayan süreç içerisinde mekân kavramı oldukça önemli değişikliğe uğramış, bilgisayar ekranları süreç içinde paralel bir evrene açılan kapı konumuna gelmiştir (Özener, 2003). Bilgi teknolojilerinin getirdiği kavramlar içerisinde mekân ve zaman yeni varlıkları ile gündeme gelmekte ve yaratılan ortam, sanal mekân kavramı ile literatürde tanımlanmaktadır (Önen, 2016).

Foucault (2005) başka mekânları "heterotopya" olarak tanımlamaktadır. Heterotopya kavramı Foucault için doğrudan mekânla ilişkili olmakla birlikte, kelimenin kökeni tıbbi bir terimdir. Terim tıp literatüründe, olması gereken yerde olmayan, yer değiştirmiş bir organ ya da bedenin bir bölümünü ifade etmek için kullanılmaktadır (Göker, 2017). Foucault, heterotopyaları çözümlemeye, mekân olgusu üzerinde durarak başlamakta ve içinde bulunduğumuz dönemi, bir mekân dönemi olarak nitelendirmektedir. Temel olarak mekânı; eş zamanlının, yan yananın ve kopuk kopukluğun kesiştiği bir alan olarak değerlendirmektedir. Foucault, bu mekânları "ütopya" ve "heterotopya" olarak iki başlık altında tanımlamaktadır. Ütopya ile heterotopya, çelişen özellikleri nedeniyle birbirinden farklı mekânlardır. Ütopyalar; toplumun gerçek mekânı ile doğrudan ya da tersine dönmüş genel bir analoji ilişkisi sürdüren mekânlar olarak tanımlanmaktadır. Ütopyalar, genellikle toplumun karşısında konumlandırılmış gerçek dışı olan mekânlardır. Heterotopyalar ise var olan, gerçek mekânlar olarak tanımlanmaktadır. Bu yönüyle heterotopyalar, ütopya kavramının karşısında durarak tezatlık göstermektedir. Foucault'nun bitişmeler çağının, yakınlık ve uzaklık çağının, yanyanalığın, dağılma ve ayrılmaların çağının gerçekliğini eşelediği yer ise ütopyalar değil heterotopyalarıdır ki bu bağlamda heterotopyalar; bir tür karşı-topos, öte-yer olarak tanımlanmaktadır. Foucault, heterotopya mekânları; burada ya da orada olmayan, plansız, diğer bir ifadeyle kendiliğinden oluşan fiziksel ya da zihinsel alanlar ya da anlar olarak tanımlamaktadır (Göker, 2017).

Foucault, heterotopyaları tanımlarken kullandığı ayna metaforunda varlığı 'gerçek zamandan ve gerçek mekândan ötelenmiş olan' olarak tanımlamaktadır. Bir metafor olarak kullanılan ayna, hem olmayan bir yer sunması bakımından ütopya; hem de gerçeklik ile gerçek dişılık arasında sanal bir mekân algısı ürettiği için heterotopya olarak belirtilmektedir. Aynaya bakıldığında kişi, kendini öteki olarak algılamaktadır. Foucault ayna metaforu ile özne konumunu oluşturan güçlerin, özne konumlarına dayalı farklı mekân oluşumunu betimlemektedir (Foucault, 2005). Bu metafor; burası ile orası, gerçek ile sanal; bize ait mekân ile yabancı mekân gibi farklı mekân tanımlamalarını öznenin konumuyla ilişkilendirmektedir. Heterotopyalar, aynanın karşısındaki gerçek yerde bulunanı belirlemektedir. Kendine bakan özne geri gelip yerini bulunca heterotopyalar alanına girmektedir (Göker, 2017).

Heterotopik mekânları tanımlarken kullanılan ayna metaforundaki özne, sanal gerçeklik oyunları özelinde değerlendirildiğinde 'oyuncular' olarak tanımlanabilmektedir. Oyuncular, 
gerçek olmayan zaman ve mekânda ötelenmiş olarak yeni bir heterotopya mekânında kendi yanılsamalarını bulmaktadır. Oyuncunun aynı anda hem sanal dünyada hem de fiziksel olarak dünyada bulunmasıyla çoklu bir mekân, zaman ve kimlik algısının ise oyunlara göre değişkenlik göstermesi ile ise zamansal bölünebilme sunmaları nedeniyle sanal gerçeklik oyunları birer heterotopya olarak tanımlanabilmektedir (Foucault, 2005).

\section{Sanal Gerçeklik Oyunlarındaki Mekân Algısı}

Sanal gerçeklik, temelde sibernetik öğelerin fizik mekânla ilişkisel olarak üst üste çakıştırılmasına ve bunun özne tarafından mekânsal olarak deneyimlenmesine olanak sağlayan bir bilgisayar teknolojisidir (Kut, 2013).

Oyuncu sanal mekânı yorumlarken, gerçek mekânı algıladığı durumdakine benzer bir süreç yaşamaktadır. Kişi sanal deneyimde fiziki dünyanın içerisindedir fakat duyu organları, bilişsel ve motor yetenekleri sanal gerçeklik sistemi tarafından gelen verileri yorumlamaktadır. Sanal mekâna adaptasyon süreci, gerçek mekânların fiziki kuralları başarıyla taklit edildiği ölçüde ivme kazanmaktadır. Sanal mekânlar oyuncuya mekân ile ilgili bilgi alışverişinde bulunma olanağı tanımaktadır. Bu bilgi alışverişinin sağlanması ise arayüzler vasıtasıyla gerçekleştirilmektedir. Oyuncunun mekâna adapte olabilmesi ve algılanabilirliğinin arttırılması için bu arayüzler bir köprü vazifesi görmektedir. Oyuncu ve oyun arasında tanımlanan arayüz kavramı aslında kullanıcının sanal dünya ile nasıl haberleşeceğini tanımlamaktadır (Kılıç, 2016).

Kullanıcı sanal gerçeklik sisteminden elde ettiği başta görsel olmak üzere çeşitli duyusal geri bildirimler ile orada olma deneyimini yaşayarak mekân ile gerçek zamanlı bir etkileşime geçmektedir. Bilişim teknolojilerinin gelişmesi ile birlikte yeni mekân deneyimlerini olanaklı kılan etkileşim yöntemleri ortaya çıkmıştır. Bu yeni arayüz ve etkileşim biçimleri sayesinde fiziki mekân - siber mekân ikilemi yerine tüm katmanlarının bir arada var olduğu bütüncül bir yeni mekân olgusu olanaklı hale gelmektedir (Kılıç, 2016).

McLuhan'a (1964) göre teknolojinin bireyin algıları üzerindeki etkileri hızlı bir kültürel dönüşüm sağlamaktadır. Virilio (1999) ise bu duruma eleştirel bir bakış açısı getirmektedir. Yeni iletişim araçlarının uzak olanı yakın kılma ve sundukları etkileşim özellikleri nedeniyle gerçek bedenin yerini sanal bedene bıraktığını ifade etmektedir. McLuhan (1964) teknolojiyi bedenin bir uzantısı olarak tarif ederken; Virilio (1999) ise tam tersi teknolojiyi bedenin eksilmesine, ihmal edilmesine neden olan bir olgu olarak tanımlamaktadır (Kut, 2013).

$\mathrm{Bu}$ bağlamda sanal mekân algısının şekillenmesinde teknoloji-beden ilişkisi önem kazanmaktadır. Sanal içeriğin mekânın katmanlarına eklemlenmesi ile bedenle kavranan mekânda veya mekânın kavradığı bedende belirli deneyimleri birleştirerek sanal mekânların bedeni ihmal etmek veya eksiltmek yerine, bedeni uzantılayarak yeni mekânsal katmanların keşfine olanak sağladığı düşünülmektedir.

\section{PUBG Sanal Gerçeklik Oyunu}

PUBG (PlayerUnknown's Battlegrounds), oyuncuların tek bir harita üzerinde birbirini yok etmeye çalıştığı; bireysel, iki kişi veya dört kişilik gruplar halinde oynanabilen, aksiyon tabanlı ve interaktif bir sanal gerçeklik oyunudur. Oyunda 4 farklı harita seçeneği bulunmaktadır. Seçilen her bir haritada en fazla 100 oyuncu oynayabilmektedir. Oyuncular, seçilen harita üzerinde istedikleri herhangi bir bölgeye uçuş güzergâhına göre iniş yaparak gerekli envanterleri toplamaktadır. Oyundaki amaç bireysel veya takım halinde hayatta 
kalarak galip olmaktır. PUBG oyunu oyunculara; Erangel, Sanhok, Vikendi, Miramar olmak üzere 4 farklı sanal mekân seçeneği sunmaktadır (bkz. Çizelge 1, Şekil 1). Bu kurgulanmış senaryo ile birlikte mekânlar şekillenmekte ve oyuncu hareketleri yönlendirilmektedir.

Çizelge 1. PUBG oyun haritaları alansal ölçümleri

\begin{tabular}{lcccc}
\hline & $\begin{array}{c}\text { Boyut } \\
(\mathrm{km})\end{array}$ & $\begin{array}{c}\text { Arazi Alan } \\
(\%)\end{array}$ & $\begin{array}{c}\text { Sulak Alan } \\
(\%)\end{array}$ & $\begin{array}{c}\text { Toplam Alan } \\
(\mathrm{km} 2)\end{array}$ \\
\hline Erangel & $8 \times 8$ & 51,47 & 48,53 & 64 \\
Sanhok & $4 \times 4$ & 49,26 & 50,74 & 16 \\
Miramar & $8 \times 8$ & 80,59 & 19,41 & 64 \\
Vikendi & $6 \times 6$ & 40,29 & 59,71 & 36 \\
\hline
\end{tabular}

Çalışma kapsamında sanal gerçeklik oyunlarındaki kurgulanmış mekânların, kentsel organizasyona benzer mekân algısı yaratıp yaratmadığı sorgulandığı için;

a. Erangel haritasının PUBG oyununun piyasaya sürülen ilk haritası olması

b. Erangel sanal mekânının 64 kilometrekarelik toplam alanı ile oyuncuya daha fazla süre oyunda kalma firsatı sunması

c. Erangel 'da yeşil alanlar, büyük binalar, küçük sayfiye evleri, limanlar, hastane, okul, tarihi mekânlar, köprüler, hapishane (bkz. Şekil 2) gibi kentsel organizasyon yapısına benzer mekânların bulunması nedenlerinden dolayı çalışma kapsamında incelenmektedir.

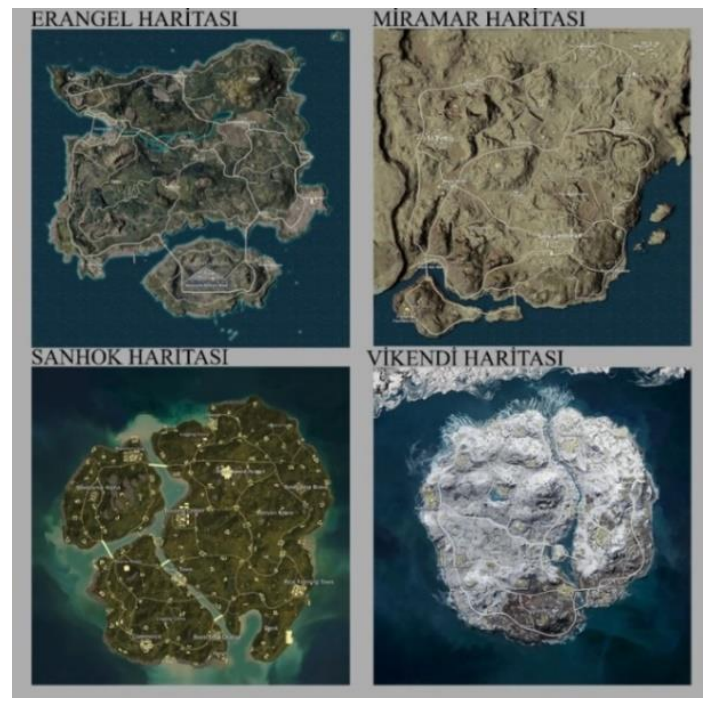

Şekil 1. PUBG oyun haritaları (URL 1)

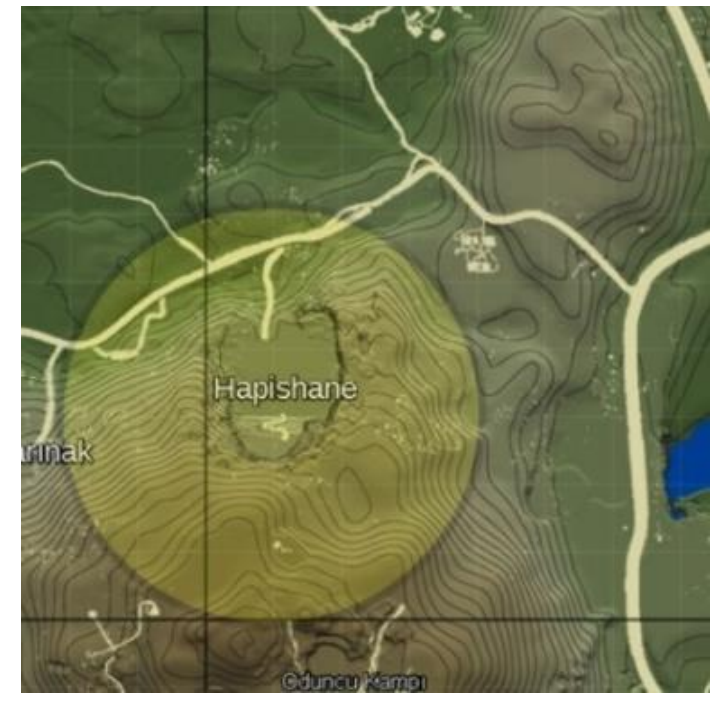

Şekil 2. Erangel eğim haritasında hapishane bölgesi (URL 1)

\section{PUBG ‘Erangel’ Sanal Mekânına Yönelik Araştırma Bulguları}

Çalışma kapsamında, sanal gerçeklik oyunlarının birer heterotopya olarak değerlendirilmesinin sebebi; sanal mekânların gerçek mekânlar üzerindeki kurucu ve değiştirici etkisine mekânsal analiz teorileri üzerinden dikkat çekmektir. 


\section{Foucault heterotopyasına yönelik heteroptik mekân değerlendirmesi}

Foucault heterotopyaları betimlemek için temelde 6 ilke belirlemiştir. Bu temel ilkeler, sanal gerçeklik oyunlarının bir heterotopya formunda anlamlandırılmasına olanak tanımaktadır. Sanal gerçeklik oyunlarının heterotopya olarak değerlendirilmesi, sanal mekânlardaki organizasyonun daha iyi ve derinlikli anlaşılmasına katkı sağlayacaktır.

i) Heterotopyaların ilk özelliği, her kültürde tek bir evrensel türü olmayan çok çeşitli biçimler alabilen yerler olmalıdır. Foucault'ya göre her toplumun ve dönemin içerisinde barındırdığ 1 farklı heterotopyalar bulunmaktadır. Foucault heterotopya kavramını 2 başlık altında incelemektedir. Bunlardan ilki ilkel toplumlara ait olan kriz heterotopyaları diğeri ise modern toplumlara ait sapkınlık heterotopyalarıdır. Sapma heterotopyalarının en temel özelliği, içerisinde bir kapatma pratiğinin olması ve bireylerin toplumdan yalıtılmasıdır. Modern toplumdaki sapma heterotopya mekânlarından birisi şüphesiz ki hapishanelerdir. Sapma mekânlarının toplumsal olanın dışına itilmesi söz konusudur (Adal, 2004).

Bir sanal gerçeklik oyunu olan PUBG'de ise bu oluşum heterotopyadan bağımsız işlemektedir. Oyunun içerisindeki normlar ve davranışlar, toplumsal kurallar ve kabullerden farklı işleyen öznel oluşumlardır. Bu bağlamda heterotopya mekânlar teknoloji ile birlikte sanallığın içerisinde dönüşüme uğramaya başlamıştır. Erangel'daki hapishane bölgesinin (bkz. Şekil 2) adanın kenarında ve çukur bir bölgede yer alıyor olmasının tesadüfi bir yer seçimi olduğunu düşünmek yanlış olacaktır. Foucault'nun tanımlamış olduğu sapma heterotopyaların en temel özelliği bir kapatma pratiğinin olması ve bireylerin toplumdan yalıtılmasıdır. Bu şekilde, sapma davranışlarının toplumsal görünürlük düzeyi düşürülmeye çalışılmaktadır. Foucault'a göre sapma heterotopyalar, toplumsal alanın dışına itilmektedir. Bu bağlamda Erangel, her ne kadar heterotopya mekânlarının biçim değiştirmiş hali olarak değerlendirilse de içerisinde bulundurduğu bazı alanlar Foucault'nun tanımlamış olduğu sapma heterotopyanın mekânsal izlerini taşımaktadır. Sonuç olarak PUBG oyunu Erangel mekânı, sanallığın içerisinde biçimi değişmiş bir heterotopya olarak tanımlanmakta ve gerçek mekânların izlerini taşıyarak bir kentsel organizasyon yaratmaktadır.

ii) Foucault'ya göre heterotopyaların ikinci özelliği ise toplumsal ve kültürel çeşitlilikle birlikte farklı işlevlerle yükleniyor olmalarıdır. Tarihsel değişim ve dönüşümler toplumsal yapıyı da değiştirerek heterotopyaların işlevlerini dönüştürmektedir. Bu bağlamda Foucault mezarlıkları birer heterotopya olarak tanımlamaktadır. Mezarlıklar 18.yy'ın sonuna kadar kent içerisinde yer alan, ölümsüzlükle ilişkilendirilen mekânlardır. Fakat sonraki yüzyıllarda ölümün bireyselleştirilmesi ile mezarlıklar şehrin dışına taşınmış ve ölüler ile yaşayanlar arasına sınır çeken öteki bir mekâna dönüşmüştür (Adal, 2004).

Oyunlar doğuşu itibariyle belirli bir amaca ve ihtiyaca hizmet etmektedir. Oyunların var oluşunun temel sebebi ise kendisini ortaya çıaran eğlence arzusunun ta kendisidir. Foucault'nun heterotopyasında tanımlamış olduğu bu tarihsel değişim ve dönüşüm toplumun eğlence anlayışını da değiştirmiştir. Eğlenme arzusundaki bu değişim, oyunların işlevlerini farklılaştırarak oyun tahtalarını gerçeklikten sanallığa taşımıştır. Bu bağlamda PUBG sanal gerçeklik oyunundaki Erangel mekânının bir heterotopya olduğu söylenebilir.

ii) Üçüncü temel ilke ise heterotopyaların kendi içlerinde bağdaşmayan birçok mekânı ve mevkii tek bir gerçek yerde yan yana koyma gücüdür. Foucault bu özelliği taşıyan heterotopyalara tiyatro ve sinema mekânlarını örnek göstermektedir. Foucault’a göre bu 
mekânlar hem gerçek mekân ve kişileri hem de kurgusal mekân ve kişilikleri bir araya getiren heterotopyalardır (Adal, 2004).

Laurel (1991)'in bilgisayarları tiyatro ile ortak özellikleri olan bir ortam olarak değerlendirmektedir nitekim bilgisayar kullanıcıları da tıpkı tiyatro seyircileri gibi hem oyuncu hem de seyirci konumunda yer almaktadır. Sanal gerçeklik oyunları ise bu bilgisayar ağlarının içerisinde yer alan sanal bir uzama denk düşmektedir. Bu özellik kapsamında da PUBG oyunu heterotopya olarak tanımlanabilmektedir.

iv)Dördüncü ilke ise heterotopyaların zamansal boyutu ile ilgilidir. Foucault'a göre heterotopyalarda insanların geleneksel zamandan kopması ve başka bir zamansal düzenlemenin içerisine girmesi söz konusudur. Foucault heterotopyaların zamansal birikmelere neden olduğunu ifade ederken bunlara müze ve kütüphaneleri örnek vermektedir, müzeler ve kütüphaneler geçmiş zamanları tek bir mekânda toplayan heterotopyalardir (Adal, 2004).

Sanal gerçeklik oyunlarının yapısal olarak zamansızlık kavramını güçlü bir şekilde beslediği görülmektedir. Bu oyunlar geleneksel zamandan kopuşu zorunlu kılarak oyuncuya farklı zaman deneyimleri yaşatmaktadır. Bu durum PUBG oyunu üzerinden değerlendirildiğinde; bazı oyunlar sadece gündüz periyodunda oynanırken, bazı oyunlar gece-gündüz periyodunda oynanmaktadır. Oyunun yapısındaki bu sonsuz gündüz ve gündüz-gece durumu yeni ve başka bir zaman algısı üretmektedir. Oyundaki gece-gündüz bölümü çizgisel akıp giden ve kaybolan bir zamanı temsil ederken, sürekli olarak gündüz oynanan oyun üst üste biriken fasılasız bir zamanı temsil etmektedir. Bu bağlamda PUBG oyuncularının zamansızlığı deneyimledikleri görülmektedir.

v) Beşinci ilke ise heterotopyaların açılma ve kapanma olgusu ile ilgilidir. Foucault'a göre heterotopyalar açılmış ya da yalıtılmış mekânlardır. İçerisine alırken aslında dışarıda bırakan ve öteleyen bu mekânlar bir taraftan tecridi, diğer taraftan nüfuz edilebilir olmayı içermektedir. Genel olarak heterotopik yerler, kamusal yerler gibi özgürce ve kolaylıkla ulaşılan yerler değildir (Adal, 2004).

Sanal gerçeklik oyunlarındaki mekânlar, her bireyin girebileceği bir açıklığa sahiptir. Ancak bu açılık oyundaki mevkiler için geçerli değildir. Oyun içerisindeki bu mevkilere girmek belirli kurallara bağlıdır. PUBG oyunu interaktif yapısı ile hem izole edilmiş hem de içine nüfuz edilmesi mümkün olan bir heterotopya olarak değerlendirilmektedir. Oyun, oyuncuyu içerisine alırken aslında gerçek hayattaki mekânların (ve hatta gerçek hayatın) dışında bırakmaktadır.

vi) Foucault'nun heterotopyalara ilişkin tanımlamış olduğu son ilke ise gerçek mekânlarla olan ilişkileridir. Heterotopyalar tüm mekânlarla ilişki içerisine girerek anlam kazanır ve bu mekânlar üzerinde iki türlü etkiye sahiptir. İlk etki, heterotopyaların yanılsama mekânlar üreterek gerçek mekânı da bir yanılsama mekân olarak sunmasıdır. Diğer etki ise ilk etkinin tersine, heterotopyaların daha düzenli ve mükemmel olmasıdır. Bu nedenle heterotopyalar 'öteki ve başkalaşmış' gerçek mekânlar yaratılar (Adal, 2004).

Dijital bir heterotopya olan sanal gerçeklik oyunları, kendi gerçekliğini 'gerçek' mekân yanılsamalarıyla üretmekte ve böylece gerçek mekânları da dolaylı olarak şekillendirmektedir. Foucault heterotopyaları tanımlarken her bir ilke için farklı mekânları örnek vermektedir. Ancak dijital heterotopyalar bu ilkelerin tamamıyla örtüşmekte ve tek bir heterotopik mekân özelliği göstermektedir. Bu bağlamda başlı başına bir heterotopya olan 
sanal gerçeklik oyunlarının kendi içerisinde farklı heterotopyalar üretebilmesi de oldukça doğal görünmektedir.

\section{Lefebvre (1974), Lynch (1960) ve Norberg-Schulz'un (1972) mekânsal analiz teorilerine yönelik değerlendirmeler}

PUBG oyunu Erangel sanal mekânı, dijital bir anlatı yapısı bulunduran heterotopya olarak tanımlanmaktadır. Bu tanımdan hareketle mekân ve insan arasındaki etkileşimin sanallıkta da tıpkı gerçek mekânlar gibi 'duyum' süreci ile başladığı görülmektedir. Duyumlanan mekânın, insan zihnindeki diğer bir adımı ise algı süreci ile anlam kazanmasıdır. Mekânın anlam kazanmasıyla bireydeki zihinsel haritalar şekillenmekte ve mekân imajı oluşmaktadır. Heterotopik sanal mekânlar gerçek mekânlardaki algı teorileriyle değerlendirilerek bu mekânların gerçek mekân algısı yaratıp yaratmadığı Çizelge 2'de yer alan parametreler yardımıyla incelenmiştir.

Çizelge 2. Mekânsal alg1 parametreleri (Yavuz ve Karadede, 2018)

\begin{tabular}{ccc}
\hline Kevın Lynch (1960) & Norberg-Schulz (1971) & Henri Lefebvre (1974) \\
\hline İzler & Süreklilik & $\mathrm{x}$ \\
Sınırlar & Alanlar & $\mathrm{x}$ \\
İşaret Ögeleri & $\mathrm{x}$ & Eşzamanlılık \\
Odaklar & $\mathrm{x}$ & Merkezileşme \\
Bölgeler & $\mathrm{x}$ & İlişkiler \\
\hline
\end{tabular}

İzler ve süreklilik: Her mekânda bir yön kavramı bulunmaktadır. Sanal mekânlardaki yön kavramı ise öklid uzayındaki dönüşler olarak tanımlanmaktadır. Sanal gerçeklik oyunlarında, oyuncu mekâna giriş yaptığı konumu terk ederek amacına göre kendine yeni yollar oluşturmaktadır. Lynch, izleri hareket kanalları olarak yorumlamaktadır, bu yorumdan hareketle oyuncunun hareket edebildiği her düzlemin zihin haritası bileşeninde yer edebildiği söylenebilir. Harita üzerinde gösterilen yollar, oyuncunun engele takılmadan hareketini sağlayabileceği izlerdir. Fakat oyun alanındaki izler sadece bunlarla sınırlı değildir. Oyuncu harita üzerindeki bütün mekânları kullanarak yön değiştirebilmektedir. Bu durum gerçek mekânlardaki yaya hareketi ile benzerlik gösterse de sanallıktaki engelleri aşmak gerçek hayata nazaran daha kolaydır. Oyuncu, oyun alanı içerisindeki evleri rahatlıkla aşabilirken, gerçek mekânlarda hareket sınırlandırılmıştır. Oyuncudaki yönlenme durumu, oyun başlangıcındaki güzergâha ve daralan oyun alanına göre değişim göstermektedir. Bu bağlamda Erangel'daki izler, yol bağlantıları ile kabataslak tanımlanmış olsa da yalnızca bu bağlantılar ile sınırlı değildir. İzlerin sanal mekânlardaki sürekliliği korunmuş, avatarın kolaylıkla aşabileceği engeller sayesinde izlerdeki bölünme durumu ortadan kaldırılmıştır. Gerçek mekânlardaki izlerin süreklilikleri kentsel elemanlarla kesilebilirken, sanallıkta bu durum aşılması kolay engeller haline dönüşerek oyuncunun hareket kabiliyetini arttırmaktadır.

Sınırlar ve alanlar: Erangel, ada şeklinde tasarlanmış bir sanal mekândır. Ada formunda oluşu sanallıktaki mekân sınırlarının en temel göstergesidir. Mekânları sınırlandırmak, oyuncu hareketinin kontrol edilmesi ve oyun kurgusunun oluşturulması için en temel adımdır. Lynch'in tanımlamış olduğu sınırlar gerçek mekânlardaki aşılması zor engeller olarak yorumlanabilirken, sanal mekânlarda bu kavram daha esnektir. Yön kavramında bahsedilen engelleri kolay aşabilme durumu, sınırlar içinde geçerlidir. Gerçek mekânda bina 
cepheleri, akarsular birer sinır olarak tanımlanabilirken, sanal mekânlarda ise sinırı kavramını oyuncu avatarının erişemediği alanlar için kullanılabilmektedir. Erangel'daki sınırlandırma en çok bariyerler ve tel örgüler ile kurgulanmıştır. Avatar bu sınırları aşamaz ve oyuncu yön değiştirmek zorunda kalır. Bu bağlamda gerçek mekânlarda sınırlar aşılması güç, insan hareketinde yön değiştirici etkiye sahipken; sanal mekânlarda sınırlar oyunun izin verdiği ölçüde hareketleri kısıtlayabilmektedir.

İşaret ögeleri ve eşzamanlılık: PUBG oyunu teknolojik mekânları içerisinde barındıran bir heterotopya türüdür. İçerisindeki mekânlar tıpkı gerçek mekânlardaki gibi ölçülebilir bir fiziki yapıdadır. Lynch'in tanımlamış olduğu yer işaretleri tıpkı gerçek mekânlardaki gibi sanal mekânlarda da belirgin referans noktalarıdır. Oyuncuların akıllarındaki referans noktalarını tanımlarken zorlanmadıkları ögeler nirengileri oluşturmakta ve bu oluşum eşzamanlı olarak oyuncuların eylemlerini gerçekleştirmesine olanak sağlamaktadır. Böylelikle oyun ile oyuncu arasındaki ilişki, zaman ve mekân akışında ortaya çıkmaktadır. Fakat oyundaki zaman kavramı gerçek zamandan farklı seyretmekte ve kurulan ilişki kısıtlanmaktadır. Bu bağlamda zaman ve mekân referansına yardımcı olan eşzamanlı ilişkiler, sanal mekânlarda nirengi noktaları ve sahte zamanlar olarak dönüşüme uğramıştır. $\mathrm{Bu}$ nedenle sanal mekânlardaki ilişkiler, gerçek zamanlardaki eşzamanlılık ilkesi ile örtüşmemekte, kendine özgü yeni bir zaman ve mekân algısı yaratmaktadır.

Odaklar ve merkezileşme: PUBG iletişim ve etkiletişim ağlarında yer alan bir sanal gerçeklik oyunudur. Bu nedenle oyun içerisinde yer alan fiziksel çevre; izlerin kesiştiği meydanlar, kavşaklar, aktarma alanları anlamındaki ulaşım mekânları ve diğer toplanmadağılma mekânları odak mekân olarak tanımlanabilmektedir. Oyuncuların yoğunlaştığı bölgeler, oyundaki izler ile doğrudan ilişkili olsa da yalnızca gerçek mekânlardaki gibi kesişim noktalarından ibaret değildir. Oyun güzergâhının elverdiği ölçüde odaklar değişebilmektedir. Oyunun başlangıcında oyuncuların uçağa bindiği bir toplanma alanı bulunmaktadır. Bu alanda 100 kişinin oyuna katılması için süre tanınmakta ve uçağa bindikten sonra haritanın istedikleri bölümüne atlayarak erişim sağlayabilmektedir. Fakat her oyunda bu güzergâh değişim göstermektedir. Bir oyuncunun erişebileceği maksimum uzaklık 1800 metre olarak sinırlandırılmaktadır. Güzergâhtan belirli mesafedeki alanlara erişim imkânının sağlanması, oyuncuların belirli odaklarda toplanarak çatışma alanının yaratılması prensibine dayanmaktadır.

Merkezileşmiş odaklar gerçek mekânlarda üretim ve tüketim faaliyetlerinin yer seçimi ile oluşmuş dağılma ya da toplanma mekânları olarak tanımlanırken, sanal mekânlarda bu durum farklı seyretmektedir. Erangel'daki hastane, okul, askeri bölge gibi mekânlar, gerçek mekânlardaki kullanım biçiminden farklı olarak hizmet etmektedir. Biçimsel olarak gerçek mekân kullanımlarına benzerlik gösteren bu alanların oyun kurgusundaki tek amacl, envanter toplama alanları olmasıdır. Bu bağlamda oyun içerisindeki odaklar, üretim ve tüketim faaliyetlerinin girdilerinden uzakta, tamamen tek amaca hizmet eden yapılı çevreler olarak karşımıza çıkmaktadır. PUBG oyunundaki odak olarak tanımlanabilecek başat mekân, oyunun başlangıcında oyuncuların beklediği toplanma alanıdır.

Bölgeler ve ilişkiler: Lefebvre, algılanan, yaşayan ve tasarlanan mekân olarak sınıflandırılan mekânın sırasıyla duyusal algı, tecrübe ve koda dayalı olduğunu savunmaktadır. PUBG ise koda dayalı tasarlanmış bir sanal gerçeklik oyunudur. Oyun içerisinde kendine özgü belirli kimlikteki kentsel bölgeler bulunsa da bu bölgeler kullanım amacı dışında yalnızca oyun ideolojisine hizmet eden mekânlar olarak karşımıza çıkmaktadır. Oyun içerisinde bulunan 
okul ya da hastane bölgesinin kullanım amacı bakımından bir farklılığı bulunmamakta daha önce de belirtildiği üzere bu alanlar oyuncunun envanter toplamasını sağlamaktır. Bu bağlamda PUBG oyunu Erangel mekânı tasarlanan bir alan olarak tanımlanırken, içerisindeki tanımlı bölgeler ile gerçek mekânların ilişkisel bölgelenmesine örnek mekânları barındırmaktadır. Fakat bu durum oyuncu-mekân ilişkisi ile değil tamamen oyunun hikâyesine göre şekillenmektedir ve sanal mekânların özünde gerçek mekân parametrelerini nasıl koruduğu gösterilmektedir. Lefebvre'nin mekân yorumu sanal mekânlar ile bağdaştırıldığında; tasarlanan mekânın görsel alg1 unsurları sayesinde algılanan mekânlara, oyuncunun tecrübesi ile ise yaşanan mekânlara dönüştügü gözlemlenmektedir (Yavuz ve Karadede, 2018).

\section{Sonuç ve Öneriler}

İnsan ve mekân deneyimi arasındaki kurulan ilk ilişki, kişinin amaca yönelik kullanımıdır. Amaca yönelik kullanımdaki en temel araç ise bedenlerdir. Beden ile kavranan mekânlar, akıldaki kavramsal kodlar ile birleşerek mekânsal algıyı oluşturmaktadır. Kişinin mekânı hatırlaması ve deneyim kazanması ile anlamlanmış mekânlar ise 'yer' olarak tanımlanmaktadır. Merleau-Ponty (2013) 'bedenimiz olmasaydı mekânlarda olmazdı' diyerek bedenleri atıp sıyrılamadığımızdan ve mekânlara bağımlı olduğumuzdan bahsetmektedir. Fakat bu durum sanal mekânlar için geçerli değildir. Mekânların neredeyse bedene mecbur olmadan var olabileceği savını sanal mekânlar doğrular niteliktedir. Ekran başında rahat, güvende ve hatta bazen evde hissedilen paralel evren, insanlar için 'yer' olmaya başlamaktadır. Bu durumda da bedensiz mekânların varlığı 'yer' kavramıyla daha net ifade edilmektedir. Yerler yalnızca geometriye bağımlı değil aynı zamanda ilişkiselliği içeren, akıldaki bir deneyimlemedir. Bu nedenledir ki algılanan, tanınan ve hatırlanan mekânlar zamanla 'yerlere' dönüşmektedir.

Küreselleşme ile başlayan teknolojik gelişmeler mekânlar üzerinde de büyük değişimlere neden olmuştur. Bu değişim özellikle insanların eğlence alanlarını değiştirmiş, eğlenme arzusu gerçeklikten sanallığa doğru yön değiştirmeye başlamıştır. Bu yönelim 'sanallıktaki gerçeklik' olgusunu doğurarak bedensiz mekânların keşfine olanak sağlamıştır. Teknolojinin zaman ve mekân algısındaki dönüştürücü etkisi oyun tahtalarını değiştirmiş, eğlenme arzusu somut tabanlı sanal mekânlara taşınmıştır.

Oyuncular için 'yerlere' dönüşen bu sanal mekânların temelini gerçeklikten alması bu ortamlardaki algılanabilirlik düzeyini ölçmeyi gerekli kılmaktadır. Gerçek mekân parametrelerini içerisinde barındırması ve bu parametrelerin sanallık ile şekillenmesi sanal ortamların başkalaşmış yönüne dikkat çekmektedir. Bu başkalaşmış sanal ortamlar mekân ve yer tanımlamalarına ek başka bileşenlere ihtiyaç duymaktadır. Foucault (2005), başka mekânları heterotopya olarak tanımlamaktadır. Sanal mekânların daha net tanımlanması için gerekli olan teoriler ise 'heterotopik mekân' bileşenleridir. Foucault heterotopyaları tanımlarken altı ilke belirleyerek her bir ilke için farklı mekânları örnek göstermiştir. Sanal mekânlar ise bu ilklerin tamamiyla örtüşerek tek bir heterotopik mekân özelliği göstermektedir. Bu bağlamda başlı başına bir heterotopya olan sanal gerçeklik oyunlarının kendi içerisinde farklı heterotopyalar üretebilmesi de oldukça doğal görünmektedir. Çalışma kapsamında, sanal gerçeklik oyunlarının birer heterotopya olarak değerlendirilmesinin ana sebebi sanal mekânların gerçek mekânlar üzerindeki kurucu ve değiştirici etkisine dikkat çekmektir. 
Çizelge 3. Gerçek mekân ve Erangel sanal mekânına yönelik değerlendirme

\begin{tabular}{|c|c|c|}
\hline Parametreler & Gerçek Mekân & Sanal Mekân \\
\hline İzler ve Süreklilik & $\begin{array}{l}\text { Hareket kanalları ve koordinat } \\
\text { akslarının sürekliliği kentsel } \\
\text { elemanlarla kesilebilir, kişinin } \\
\text { hareket durumu kısıtlanır }\end{array}$ & $\begin{array}{l}\text { Oyuncunun hareket edebildiği } \\
\text { izler daha sürekli, izleri bölen } \\
\text { ögelerin aşılması kolay, } \\
\text { oyuncunun hareket kabiliyeti } \\
\text { yüksek }\end{array}$ \\
\hline Sinırlar ve Alanlar & $\begin{array}{l}\text { Sinırların tanımlamış olduğu } \\
\text { alanlar yoğunlukta, sınırlayıcı } \\
\text { ögeler alan oluşumunu kontrol } \\
\text { eden sınır, kişi hareketinin } \\
\text { yönlendirir }\end{array}$ & $\begin{array}{l}\text { Sınırlar oyunun izin verdiği } \\
\text { sürece hareketi kısıtlar, alan } \\
\text { oluşumu sınırlara bağll değil } \\
\text { oyun ideolojisi ile ilişkilidir }\end{array}$ \\
\hline İşaret Ögeleri ve Eşzamanlılık & $\begin{array}{l}\text { İşaret ögeleri zaman ve mekân } \\
\text { referansına yardımcı olan } \\
\text { eşzamanlı ilişkilerin ürünüdür }\end{array}$ & $\begin{array}{l}\text { İşaret ögeleri, zaman ve mekân } \\
\text { arasındaki ilişkilerden } \\
\text { bağımsız olarak } \\
\text { şekillenmektedir, zaman } \\
\text { kavramı sonsuz olduğu için } \\
\text { eşzamanlılığı yoktur }\end{array}$ \\
\hline Odaklar ve Merkezileşme & $\begin{array}{l}\text { Merkezileşmiş odaklar üretim } \\
\text { ve tüketim faaliyetlerinin yer } \\
\text { seçimi ile oluşmuş dağılma ya } \\
\text { da toplanma mekânlarıdır }\end{array}$ & $\begin{array}{l}\text { Merkezileşen odaklar, üretim } \\
\text { ve tüketim ilişkilerinden } \\
\text { uzakta, tamamen oyun } \\
\text { ideolojisine ilişkin olarak tek } \\
\text { amaca hizmet etmektedir }\end{array}$ \\
\hline Bölgeler ve İlişkiler & $\begin{array}{l}\text { Bölgeler; tasarlanan, algılanan } \\
\text { ve yaşanan mekânlar } \\
\text { arasındaki ilişkilerin ürünüdür }\end{array}$ & $\begin{array}{l}\text { Bölgeler tasarlanmış alan olup } \\
\text { oyuncu-oyun arasındaki } \\
\text { tecrübe ve zaman ilişkisi ile } \\
\text { yaşanan ve algilanan alanlara } \\
\text { dönüşmektedir }\end{array}$ \\
\hline
\end{tabular}

Çalışma kapsamında PUBG oyunu Erangel mekânının kentsel organizasyona benzer mekân algısı yarattığı gözlemlenmiş olup (Çizelge 3) mekânsal algı teorilerinin sanal mekân algısı değerlendirmesinde yetersiz olduğu saptanmıştır. Çalışma neticesinde sunulan öneri ise sanal mekânların planlama ile bütüncül olarak kullanımıdır. Teknolojinin gelişmesi ile birlikte planlama prensibine de entegre olan sanal mekânlar, kullanıcının tasarım aşamasındaki bir mekânı içinde dolaşarak değerlendirmesine olanak sağlamaktadır. Sanal ve gerçek mekânlarda bireylerin benzer davranışlar gösterdiği, simülasyon çalışmaları ile kanıtlandığı durumda daha yaşanabilir ve kullanıcıya uygun çevreler oluşturma imkânı artar. Böylelikle plancılar ve mimarlar tasarım sürecinde kişi hareketlerini gözlemleyerek problemli bölgeleri yeniden tasarlama imkânına sahip olabilmektedir. Fakat sanal mekânların nitelikli olarak okunması için gerçek mekânlardan ayrı olarak ek parametrelere ihtiyaç duyulmaktadır. Bunun en temel sebebi ise sanal mekân kullanımındaki bedensizliktir. Sanal mekân simülasyonlarının gerçek mekân kullanımlarına girdi sağlaması için; bedenin uzantılanmasıyla mekânın kavranması gerekmektedir. Bu sayede kullanıcının hareketini öngörerek gelecekte bu yönelime uygun mekânlar oluşturulabilir.

\section{Kaynakça}

Adal, R. (2004). Aydınlanma çă̆ında kamusal alan ve heterotopik mekân incelemesi: "Palais Royal" ve "Mason locaları". Ankara Üniversitesi Sosyal Bilimler Enstitüsü, Ankara.

Akgül, İ. (2009). Fiziksel ve kişisel özelliklerin bilişsel haritalar üzerindeki etkileri: Sanal mekânlarda deneysel bir çalışma. Dokuz Eylül Üniversitesi Fen Bilimleri Enstitüsü, İzmir. 
Foucault, M. (2005). Başka mekânlara dair. Özne ve İktidar Seçme Yazılar, 2, İstanbul.

Göker, G. (2017). Dijital heterotopyalar: “Başka” bir bağlamda yeni medya. Selçuk Üniversitesi İletişim Fakültesi Akademik Dergisi, 9(4), 164-188.

Kılıç, T. (2016). İç mekân tasarımında kullanılan mobil artırılmış gerçeklik uygulamalarına ilişkin bir inceleme. Mimarlık ve Yaşam, 3(2), 169-187.

Kut, S. (2013). Sibertektonik mekân. İstanbul Teknik Üniversitesi Fen Bilimleri Enstitüsü, İstanbul.

Laurel, B. (1991). Computers as theatre. Menlo Park, CA: Addison-Wesley.

Lefebvre, H. (1974). The production of space. Paris: Anthropos.

Lynch, K. (1960). The city image and its elements. MIT Press, Cambridge, 41, 73.

McLuhan, M. (1964). Understanding media the extensions of man. London: McGraw Hill.

Merleau-Ponty, M. (2013). Phenomenology of perception. Routledge.

Norberg-Schulz, C. (1971). Existence, Space \& Architecture, London: Studio Vista.

Özen, A. (2006). Mimari sanal gerçeklik ortamlarında alg1 psikolojisi. Bilgi Teknolojileri Kongresi IV, Akademik Bilişim.

Özener, O. Ö. (2003). Siberuzay dokusu ve hipermetin mekân için etkileşimli bir ortam modeli. İstanbul Teknik Üniversitesi Fen Bilimleri Enstitüsü, İstanbul.

Torun, H. (2004). Bilişsel haritalandırmada etkin parametrelerin ortaya konması: İTü Ayază̆a Kampüsü örneği. İTÜ Fen Bilimleri Enstitüsü), İstanbul.

URL1:http://pubggmobile.blogspot.com/2018/08/pubg-haritalar-hakknda.html (Erişim tarihi: 08.04.2019).

Virilio, P. (1999). Politics of the very worst: An interview with Philippe Petit. New York: Semiotext.

Yavuz, A. Ö., Karadede, G. (2018). Evaluating the organization of urban environments through virtual media: the example of video games. Gazi University Journal of Science Part B: Art Humanities Design and Planning, 6(1), 9-18. 